\title{
RELATIONSHIP BETWEEN THE MUD ORGANIC MATTER CONTENT AND THE MAXIMUM HEIGHT OF DIAPIRIC DOMES USING ANALOG MODELS
}

\author{
RELACIÓN ENTRE EL CONTENIDO DE MATERIA ORGÁNICA DE LODO Y LAALTURA \\ MÁXIMA DE LOS DOMOS DIAPIRICOS USANDO MODELOS ANÁLOGOS
}

\author{
RELAÇÃO ENTRE O CONTEÚDO DE MATÉRIA ORGÂNICA DE LODO E AALTURA \\ MÁXIMA DOS DOMOS DIAPÍRICOS USANDO MODELOS ANÁLOGOS
}

\author{
Olivia González-Morales ${ }^{1-2}$, Alfonso-Luis Rodríguez-Madrid ${ }^{3}$, Carlos-Alberto Ríos-Reyes ${ }^{1 *}$ \\ and Germán-Yury Ojeda-Bueno ${ }^{4}$ \\ 'Universidad Industrial de Santander, Bucaramanga, Santander, Colombia \\ ${ }^{2}$ Geoconsulting, Bogotá, Cundinamarca, Colombia \\ ${ }^{3} \mathrm{RM}$ GeoConsulting, Vancouver, Canadá \\ ${ }^{4}$ Corporación Geológica Ares, Bogotá, Cundinamarca, Colombia \\ e-mail: carios@uis.edu.co
}

(Received: Jul. 03, 2015; Accepted: Dec. 02, 2015)

\begin{abstract}
$\mathrm{M}$ - ud diapirs are sedimentary structures produced by mud intrusion through a host rock. In this study, analog models of mud diapirism showed that gas generated from decomposition of organic matter contained in diapiric mud plays a fundamental role in the generation of these structures. This study is aimed to test the hypothesis that a relationship exists between the mud organic matter content (TOC) and the maximum height of diapiric domes. Our experiments were performed using sand boxes $20 \times 20 \times 16 \mathrm{~cm}$ in size, using nine mud combinations with TOC values that ranged between 1.6 and $4.3 \%$, repeated 5 times to minimize random errors. Results of this study confirm that a linear relationship of the maximum height $(\mathrm{mm})=12.7 \times \mathrm{TOC}(\%)-18.16$ explains the elevations measured. In addition, an inverse linear relationship between TOC and the time at which the domes reached $h_{\max }$ was established. Observation of the morphological changes undergone by domes during their evolution allowed recognition of evolutionary stages that can be compared to the geomorphology of mud domes in nature. The relationships established in this study are useful to generate hypothesis about the organic matter content under active mud diapiric areas. For example, the elevations in the south of Colombia's Sinú diapiric Belt (Abibe-Las Palomas Anticlinorium) are, on average, clearly higher than those in the northern part of this belt (Turbaco Anticlinorium). This may be the result of a much more organic-rich mud source under the southern Anticlinorium relative to the north. Finally, a warning is made on the risks of constructions above areas where mud diapirism occurs, which can be affected by the collapse of diapiric domes.
\end{abstract}

Keywords: Mud diapirs, Sedimentary, Analog models, Gas, Organic matter, Geomorphology.

How to cite: González-Morales, O., Rodríguez-Madrid, A. L., Ríos-Reyes, C. A. \& Ojeda-Bueno, G. Y. (2015). Relationship between the mud organic matter content and the maximum height of diapiric domes using analog models. CT\&F - Ciencia, Tecnología y Futuro, 6(2), 17-32.

*To whom correspondence should be addressed 


\section{RESUMEN}

$\mathrm{L}$ os diapiros de lodo son estructuras sedimentarias producidas por la intrusión de lodo a través de una roca encajante. En este estudio, los modelos análogos de diapirismo de lodo mostraron que el gas generado a partir de la descomposición de la materia orgánica contenida en el lodo diapírico juega un papel fundamental en la generación de estas estructuras. El objetivo de este estudio fue probar la hipótesis de que existe una relación entre el contenido de materia orgánica (TOC) del lodo y la altura máxima de los domos diapíricos. Los experimentos se realizaron en cajas de arena de $20 \times 20 \times 16 \mathrm{~cm}$ de tamaño, utilizando nueve combinaciones de lodo con los valores de TOC de 1.6 - $4.3 \%$, con 5 repeticiones para minimizar los errores aleatorios. Los resultados de este estudio confirman que una relación lineal de la altura máxima $(\mathrm{mm})=12.7 \times \mathrm{TOC}(\%)-18.16$ explica las elevaciones medidas. Además, se estableció una relación lineal inversa entre el TOC y el momento en que los domos alcanzaron la $h_{\max }$. La observación de los cambios morfológicos sufridos por los domos durante su evolución permitió el reconocimiento de etapas evolutivas que pueden ser comparadas a la geomorfología de los domos de lodo en la naturaleza. Las relaciones que se establecen en este estudio son útiles para generar hipótesis sobre el contenido de materia orgánica en áreas de diapiros de lodo activos. Por ejemplo, las elevaciones en el sur del Cinturón diapírico de Sinú de Colombia (anticlinorio de Abibe-Las Palomas) son, en promedio, claramente superiores a los de la parte norte de este cinturón (anticlinorio de Turbaco). Esto puede ser el resultado de una fuente de lodo mucho más orgánica rica bajo el anticlinorio sur con respecto al del norte. Finalmente, se advierte de los riesgos potenciales a los cuales pueden estar sujetas las construcciones sobre las áreas donde ocurre diapirismo de lodo que pueden ser afectadas por el colapso de domos diapíricos.

Palabras clave: Diapiros de lodo, Sedimentario, Modelos análogos, Gas, Materia orgánica, Geomorfología.

\section{RESUMO}

O

s diápiros de lodo são estruturas sedimentárias produzidas pela intrusão de lodo através de uma roca hospedeira. Neste estudo, os modelos análogos de diapirismo de lodo mostraram que o gás gerado a partir da decomposição da matéria orgânica contida no lodo diapírico tem um papel fundamental na geração destas estruturas. O objetivo deste estudo foi provar a hipótese da existência de uma relação entre o conteúdo de matéria orgânica (TOC) do lodo e a altura máxima dos domos diapíricos. Nossos experimentos foram realizados em caixas de areia de $20 \times 20 \times 16 \mathrm{~cm}$ de tamanho, utilizando nove combinações de lodo com os valores TOC de $1.6-4.3 \%$, com 5 repetições para minimizar os erros aleatórios. Os resultados deste estudo confirmam que uma relação lineal da altura máxima $(\mathrm{mm})=12.7 \times \mathrm{TOC}(\%)-$ 18.16 explica as elevações medidas. Além disso, foi estabelecida uma relação lineal inversa entre o TOC e o momento em que os domos atingiram a $h_{\max }$. A observação das alterações morfológicas sofridas pelos domos durante sua evolução possibilitou o reconhecimento de etapas evolutivas que podem ser comparadas com a geomorfologia dos domos de lodo na natureza. As relações estabelecidas neste estudo são úteis para gerar hipóteses sobre o conteúdo de matéria orgânica em áreas de diápiros de lodo ativos. Por exemplo, as elevações no sul da Faixa diapírica de Sinú na Colômbia (anticlinório de Abibe-Las Paolomas) são, em média, claramente superiores àqueles da parte norte desta faixa (anticlinório de Turbaco). Isso pode ser resultado de uma fonte de lodo muito mais orgânica em rica sob o anticlinório sul a respeito do norte. Finalmente, advertem-se os riscos potenciais aos quais podem ficar sujeitas as construções sobre as áreas onde ocorre diapirismo de lodo que podem ser afetas pelo colapso de domos diapíricos.

Palavras-chave: Diápiros de lodo, Sedimentário, Modelos análogos, Gás, Matéria orgânica, Geomorfologia. 


\section{INTRODUCTION}

Mud diapirism and volcanism are well-known geological phenomena, which have been described onshore and offshore around the world (e.g., Higgins \& Saunders, 1974; Brown \& Westbrook, 1988; Kopf, 2002) as shown in Figure 1. Although they occur in several geological settings, the majority of the features known to date are located in compressional tectonic scenarios (e.g., Dimitrov, 2002; Kopf, 2002; Chen et al., 2014), particularly in accretionary wedges, such as the Mediterranean Ridge (e.g., Robertson, 1996; Kopf, Robertson \& Volkmann, 2000; Charlou et al., 2003), Barbados (e.g., Brown \& Westbrook, 1988; Martin et al., 1996; Sumner \& Westbrook, 2001), Costa Rica (Shipley, Stoffa \& Dean, 1990), Panama (Reed et al., 1990), Southern Caspian Sea (e.g., Jakubov, Ali-Zade \& Zeinalov, 1971; Guliyiev \& Feizullayev, 1997; Yusifov \& Rabinowitz, 2004; Antonielli et al., 2014), Gulf of Cádiz (e.g., Somoza et al., 2003; León et al., 2007; Hensen et al., 2007; Palomino et al., In Press) and Nankai Trough (e.g., Kobayashi et al., 1992; Morita et al., 2004; Nishio et al., 2015). However, mud diapirism can also occur in extensional provinces, such as the Black Sea (e.g., Krastel et al., 2003) and Southeastern Tyrrhenian Sea (e.g., Gamberi \& Rovere, 2010). On the other hand, in some cases they have been linked to both compressional and extensional settings, such as the
Western Alboran Sea area (e.g., Pérez-Belzuz, Alonso \& Ercilla, 1997; Sautkin et al., 2003). In addition to high overpressure in sedimentary layers due to rapid sedimentation and gas generation (e.g., Dimitrov, 2002; Talukder et al., 2007; Brown, 1990; Hovland, Hill \& Stokes, 1997), tectonic processes are considered to be the main driving mechanism for the development of mud diapirism (e.g., Milkov, 2000; Talukder et al., 2007). In Colombia, mud diapirism has been reported in scarce studies (e.g., Duque-Caro, 1984; Vernette et al. 1992; Briceño \& Vernette, 1992; Ordoñez, 2008). Between Galerazamba and the Gulf of Urabá (Figure 2), Oligocene to Pliocene sequences of turbidities, hemipelagic, and terrigenous marine deposits form the Sinú Belt, a stratigraphic unit strongly affected by differential tectonic movement driven in part by mud diapirism and associated phenomena (Vernette et al. 1992). This can be associated with the active Colombian Caribbean margin, which has evolved since late Cretaceous time, resulting in an intricate deformation history involving oblique subductionaccretion, extension, and tectonic inversion during the Cenozoic (Mantilla-Pimiento et al., 2009).

The aims of this study were:

1. To understand the possible relationship between the concentration of organic matter in mud and

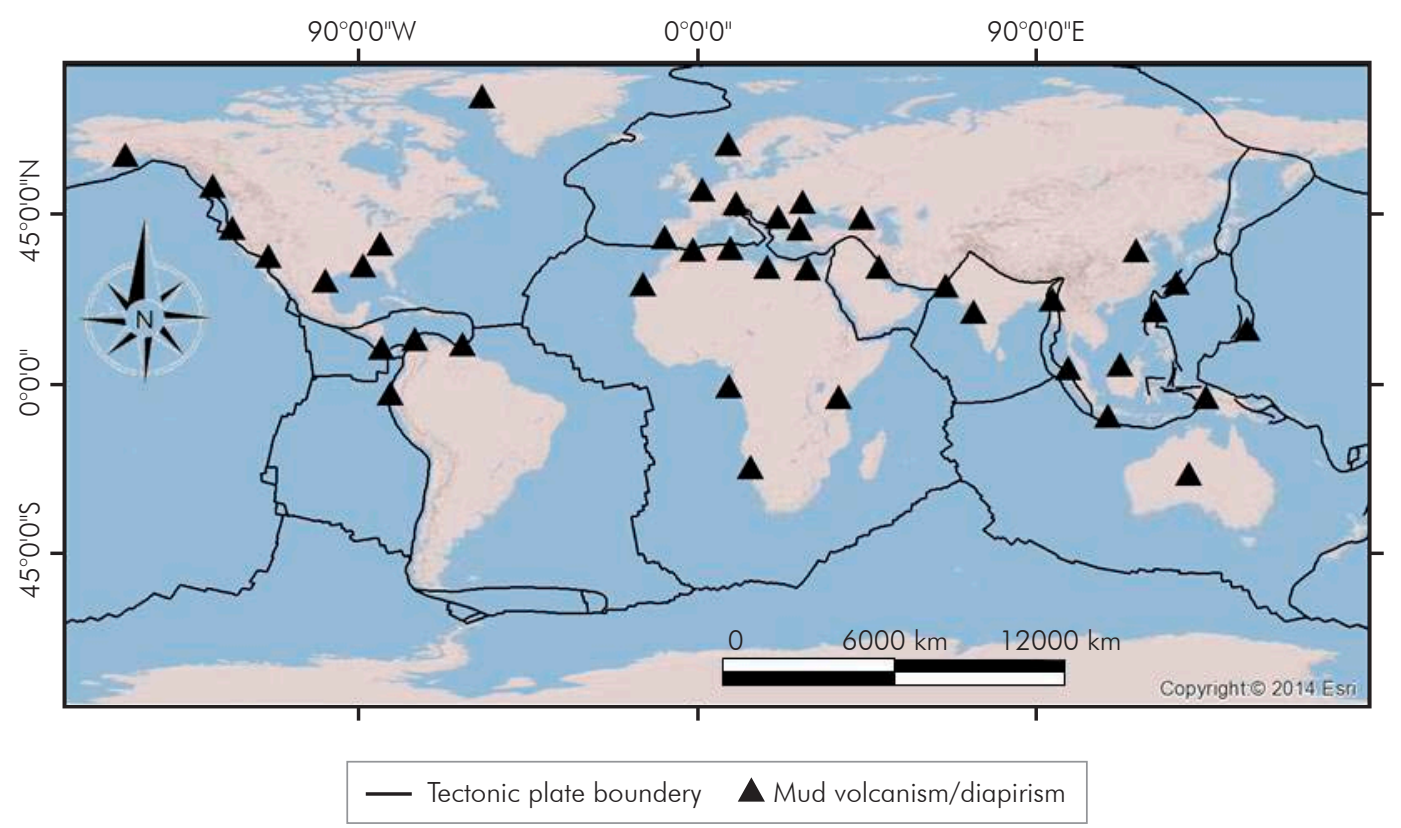

Figure 1. World distribution of mud volcanism/diapirism (modified after Kopf (2003); world imagery by Esri@ 2014). 


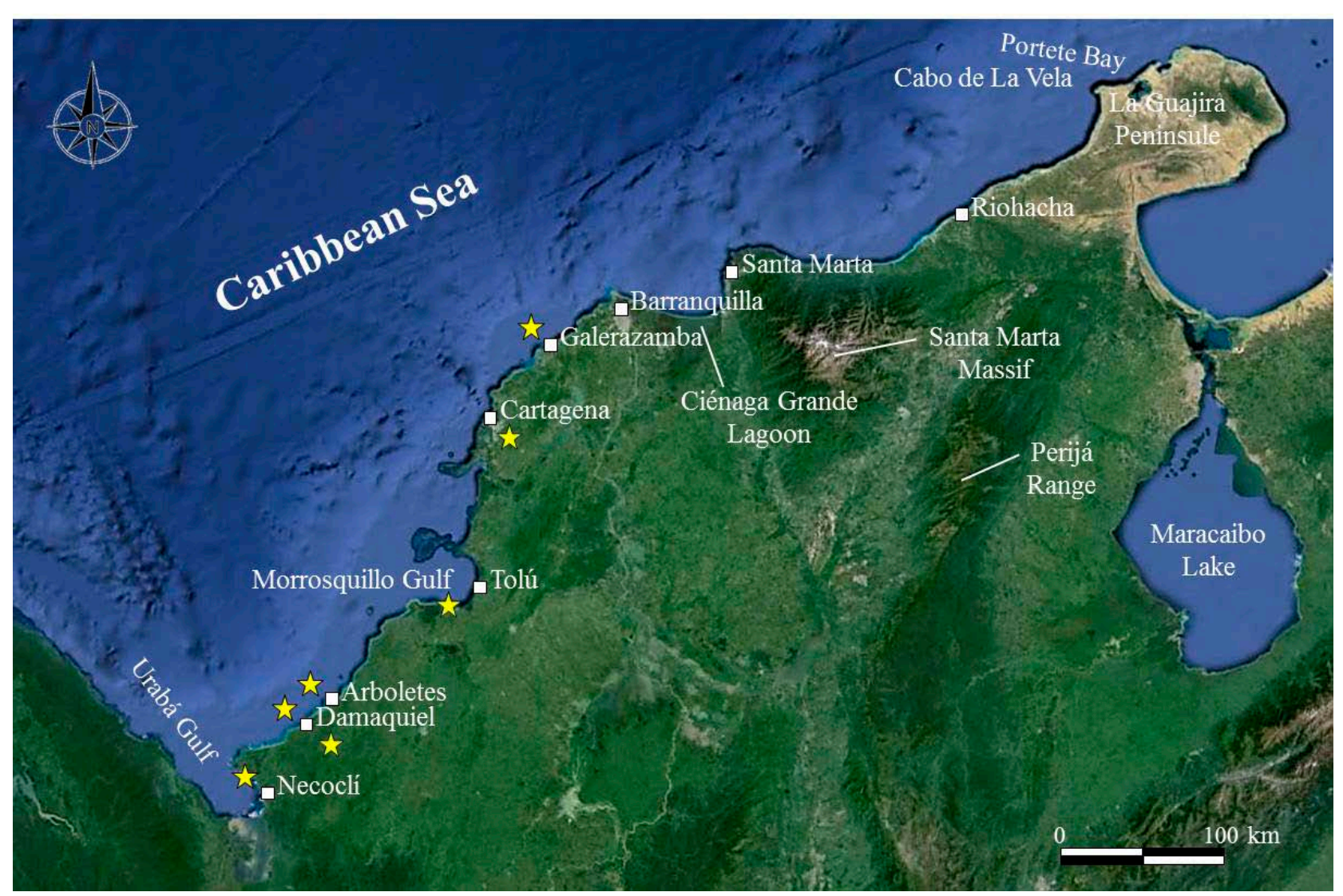

Figure 2. Satellite image showing the distribution of mud volcanism/diapirism between Galerazamba and the Gulf of Urabá (Colombia) by Google Earth.

the maximum height $\left(h_{\max }\right)$ reached by the diapiric domes, as well as the relationship between organic matter content and the rate of ascent of the domes.

2. To determine the importance of gases coming from decomposition of organic matter contained in mud as a decisive factor in the formation and transformation of mud diapirs.

3. To establish the stages of evolution of domes formed by diapirisim during their rise and collapse. This study was conducted on the basis of the working hypothesis that diapiric mud structures and dome heights depend on the concentration of organic matter contained in the diapiric mud.

Therefore, this study was focused exclusively on evaluating the role played by organic matter contained in the mud, in the formation and evolution of mud diapirs, through the implementation of physical analog models.

\section{MUD DIAPIRS AND VOLCANOES}

Mud diapirs and volcanoes are almost vertical structures formed by the ascent of mud through a rock column (O'Brien, 1968) and they appear on the surface with characteristic geomorphologic shapes such as domes and mud volcanoes (Milkov, 2000). Figure 3 illustrates a schematic diagram of formation of mud diapirs and volcanoes and associated structures. Mud diapirs are intrusive structures characterized by a slow upward migrating mass of clay-rich sediment and fluid discharge (Kopf, 2002), whereas mud volcanoes are usually found above the diapir as a result of fluid migration directly along the body of the diapir or through faults (fractures) connected to it (e.g., Milkov, 2000; Kopf, 2002). Mud volcanoes represent the last manifestation of diapirism (e.g., Brown \& Westbrook, 1988; Pérez-Belzuz et al., 1997; Kopf, 2002; PerezGarcia, 2012) as a result of extrusion of subsurface mud, fragments of country rocks, saline waters and gases. They show a variety of conical edifices whose morphology is similar to those of magmatic volcanoes, 
with central vents although smaller in size (e.g., Kopf, 2002; Antonielli et al., 2014). Mud volcanoes typically emit a mixture of gas, water, and sediment derived from deep within underlying sediments (Perez-Garcia, 2012), and the natural and relative proportions of these products, the volumes in which they are produced, and the rate and frequency of their emission all affect the shape of the surface feature (e.g., Judd \& Hovland, 2007). They represent the most important pathways for $\mathrm{CH}_{4}$ flow from deep marine sediments into atmosphere (Dimitrov, 2002). They have been studied intensively as they are closely related to the occurrence of hydrocarbons (e.g., gas hydrates) and fluid discharge (mainly $\mathrm{CH}_{4}$ and $\mathrm{CO}_{2}$ ), which is an important component of global carbon cycles (e.g., Milkov, 2000; Kopf, 2002). Gas hydrates are of particular interest due to their potential as energy resource (e.g., Hester \& Brewer, 2009). They are solid, non-stoichiometric compounds of small gas molecules and water (Sloan, 2003), and are known to be responsible for the formation of three structures; Cubic structure I, Cubic structure II and Hexagonal structure H (e.g., Lundgaard \& Mollerup, 1992; Servio et al., 1999; Uchida et al., 2006), whose formation and decomposition are first order phase transitions and not chemical reactions (e.g., Gao, House \& Chapman, 2005). Diapirs offer evidence of regional geologic phenomena, as in the Sinú Belt in the Colombian Caribbean coast, where the region intruded by diapirs is well evidenced in surface geology and in smaller proportion in the San Jacinto Belt (Duque-Caro, 1984). Subsurface over-pressure, caused by compaction disequilibrium, is also a feature typically associated to mud diapirism (Hedberg, 1974), and pose threats during the exploratory drilling. Many diapirs are escape routes of methane to the atmosphere, and thus may contribute to atmosphere warming (Beauchamp, 2004; Kopft, 2003). Mud diapirs also have biological and social implications, since they are frequently considered exotic phenomena of scientific and tourist attractiveness, and they may represent a geotechnical hazard due to the unstable ground caused by episodic discharges (which can be explosive) of mud and gas. In petroleum geology, mud diapirs are important as they may generate structural and/or stratigraphic traps, and in other cases, mud intrusion may destroy pre-existent accumulations (Ojeda, Hernández \& Olaya, 2004). Notwithstanding the large distribution of mud diapirs worldwide, there is no consensus on the mechanisms that generate diapirs, or on the relative contribution of the different variables that impact their formation and development. Mud diapirism has been related to a variety of reasons: (1) lateral compressive stresses (tectonic compression) (Kugler, 1968; Milkov,

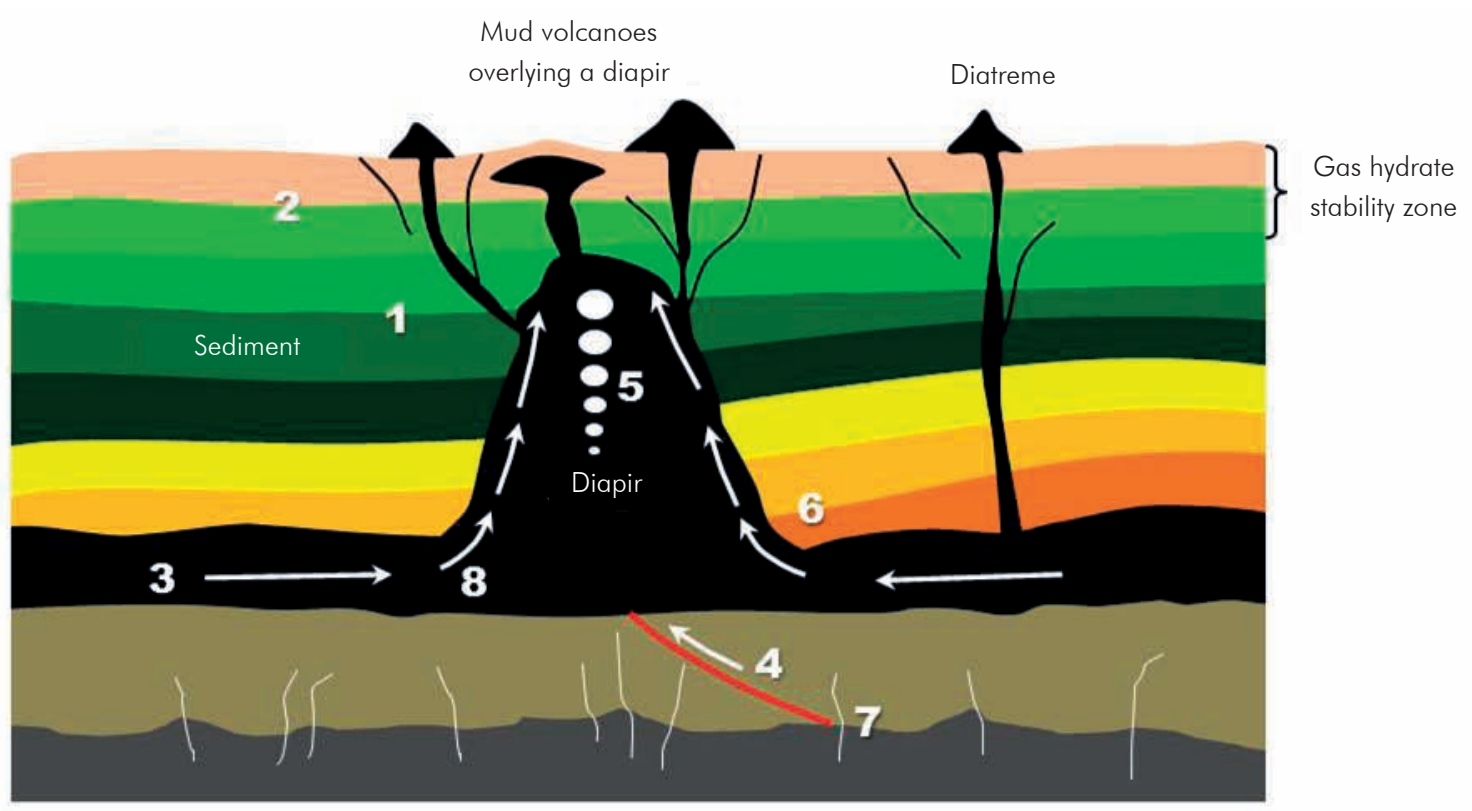

Figure 3. Schematic diagram of a diapir rising up through the sediments, developing mud diapirs and volcanoes and associated structures, including possible fluid sources: (1) pore fluid expulsion from compaction; (2) biogenic methane from degradation of organic matter; (3) lateral fluid flow through stratigraphic horizons; (4) fluid migration along deep thrusts; (5) thermogenic methane and higher hydrocarbons; (6) fluids from mineral dehydration; (7) hydrothermal fluids, alteration of crustal rock; (8) fluid expulsion from internal deformation within the diapiric intrusion. Adapted and modified from Kopf (2002). 
2000); (2) gravitational weight (Duque-Caro 1984); (3) gravity-driven ascent due to density difference between the dense overburden and lighter underlying mud rocks (Morgan et al., 1965); (4) mobilization of water-saturated mud, coming from deep formations cutting through locally deformed strata, through permeable conduits such as faults (Vernette, 1986); (5) high sedimentation rates in continental passive margins and abyssal areas of Mediterranean seas, (Milkov, 2000); (6) decomposition of gas hydrates under a seal rock, increasing pore pressure, changing the density of shales, providing additional buoyancy, serving as a propelling mechanism in the mobilization of the mud, and generating intrusions of mud through the overlaying strata (Robertson \& Kopft, 1998; Beauchamp, 2004); (7) organic matter disseminated in diapiric mud, that under attack by aerobic and anaerobic bacteria, oxidizes simple organic and inorganic compounds, reducing the $\mathrm{CO}_{2}$ to methane, which, (a) increases pore pressure, (b) increases porosity, (c) reduces density, (d) produces mass deficit which translates into negative gravity anomalies and (e) increases temperature and heat flow above normal values. These variations generate an unbalance between the mud loaded with methane and the surrounding material, which transforms mud into a plastic material of low viscosity. This material will tend to flow through the host rock, causing intrusions of mud and diapirs (Hedberg, 1974). One approach to understand the formation of diapiric structures is by means of physical analog models. Physical analog models allow isolation and control of variables that influence a system, in order to evaluate their relative contribution to the phenomenon under consideration (Schellart, 2002).

\section{MATERIALS AND METHODS}

Physical analog models are simplified laboratory replicas of natural systems, which are useful to understand and quantify different geological phenomena (e.g., Schellart, 2002; Michon \& Merle, 2003). These models require a previous experimental design that normally includes selection of adequate modeling materials, definition of an experimental assembly procedure, and determination of the number of replicas necessary to obtain statistically significant results. Thus, the results of this research are based on nine configurations where only one variable was modified (mud organic matter content measured as Total Organic Carbon (TOC)). Mud samples were ground to $<100$ mesh with subsequent carbonate dissolution with $\mathrm{HCl}$ and organic-carbon combustion using a LECO WR 112 Carbon Analyzer in order to determine the TOC. These nine configurations were repeated five times each with the purpose of obtaining repeatability in the observations and minimizing random error of the obtained results, thus adding to a total of forty five (45) different sets.

\section{Materials}

Dry quartz sand (300 to $105 \mu \mathrm{m}$ grain size) was used, which facilitated observation of deformation structures on the surface; flavorless jelly (Leader Price brand) with the purpose of creating an impermeable layer and increasing the TOC in flavorless jelly-mud mixtures (flavorless jelly, $43.2600 \%$ in weight; Organic Black Mud (OBM), 3.8020\% in weight; Standard Yellow Mud (SYM), $0.1365 \%$ in weight).

\section{Experimental Configuration}

The experiments were carried out at room temperature in rigid $20 \times 20 \mathrm{~cm}^{2}$ base and $16 \mathrm{~cm}$ height glass boxes. The fundamental configuration was as follows: A base layer of mud $7 \mathrm{~cm}$ thick, a $1 \mathrm{~cm}$ thick impermeable layer (flavorless jelly) and a top layer of sand $3 \mathrm{~cm}$ thick (Table 1, Figure 4).

For the base layer, nine different muds were implemented with different amounts of TOC. These muds were obtained from different mixtures (wt. \%) between OBM and SYM, with different quantities of

Table 1. Material properties.

\begin{tabular}{|c|ccc|}
\hline $\begin{array}{c}\text { Box (base: } 20 \mathrm{~cm} \times 20 \mathrm{~cm} ; \\
\text { height: } 16 \mathrm{~cm})\end{array}$ & $\begin{array}{c}\text { Thicknes } \\
(\mathrm{cm})\end{array}$ & $\begin{array}{c}\text { Average density } \\
\left(\mathbf{g} / \mathrm{cm}^{3}\right)\end{array}$ & $\begin{array}{c}\text { Aproximate weight of } \\
\text { lithostatic column } \\
\text { (g) }\end{array}$ \\
\hline Top Layer (Medium - Fine Sand) & 3 & 1.25 & $1450-1550$ \\
\hline Impermeable Layer & 1 & 0.31 & $115-135$ \\
\hline Base Layer (Mud Mixtures) & 7 & 1.1 & 3125 \\
\hline
\end{tabular}




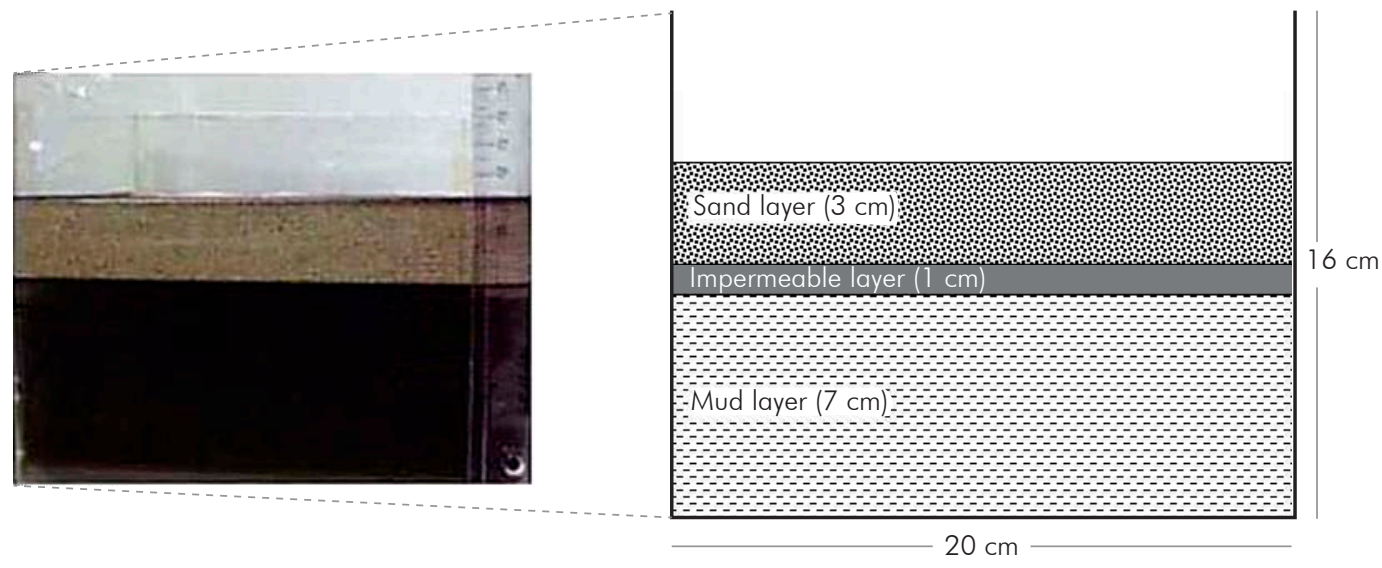

Figure 4. Initial set up. Left: Real assembly (side view) Right: Explanatory sketch.

flavorless jelly (Table 2). The final model configuration resulted from previous experiments. Early experiments allowed carrying out an inventory of appropriate variables controllable in the laboratory with the intent of selecting the variable to be modeled and postulating a working hypothesis, as well as designing the most appropriate experimental configuration, tailored to accept or reject the proposed hypothesis.

Table 2. Relationship of mud mixtures and their corresponding TOC percentage. OBM coming from the Manantial Lake (TOC $=3.8020 \%$ ), SYM coming from the Bucaramanga Formation (TOC $=0.1365 \%$ ), Gel $=$ flavorless jelly (TOC $=43.2600 \%)$.

\begin{tabular}{|cc|}
\hline Mixture & $\%$ TOC \\
\hline $6 \mathrm{~kg} \mathrm{OBM}: 4 \mathrm{~kg} \mathrm{SYM}$ & 1.65 \\
\hline $7 \mathrm{~kg} \mathrm{OBM}: 3 \mathrm{~kg} \mathrm{SYM}$ & 2.04 \\
\hline $8 \mathrm{~kg} \mathrm{OBM}: 2 \mathrm{~kg} \mathrm{SYM}$ & 2.52 \\
\hline $9 \mathrm{~kg} \mathrm{OBM}: 1 \mathrm{~kg} \mathrm{SYM}$ & 2.69 \\
\hline OBM & 3.80 \\
\hline $4 \mathrm{~kg} \mathrm{OBM}+8 \mathrm{~g} \mathrm{Gel}$ & 3.88 \\
\hline $4 \mathrm{~kg} \mathrm{OBM}+16 \mathrm{~g} \mathrm{Gel}$ & 3.95 \\
\hline $4 \mathrm{~kg} \mathrm{OBM}+24 \mathrm{~g} \mathrm{Gel}$ & 4.03 \\
\hline $4 \mathrm{~kg} \mathrm{OBM}+48 \mathrm{~g} \mathrm{Gel}$ & 4.35 \\
\hline
\end{tabular}

From this first series of models (28 in total) the following observations were made:

1. The thickness of the lithostatic column can play a negative role in the generation of mud diapirism. This observation led to reduce the thickness of the overburden sand layer from 22.5 to $3 \mathrm{~cm}$ in the final configuration. In this first set of models, gradual subsidence of the sand layer was observed to take place due to compaction of the mud layer and escape of fluids (water) toward the top.
2. Fluid leakage and mud loss could be avoided by means of an impermeable layer. Thus, during the experiment, the system was sealed with stucco plaster as well as with a flavorless jelly layer. The latter was found to be more appropriate due to its shorter dry-out time in contact with mud, as compared to the stucco plaster.

3. The gas accumulation under an impermeable seal plays a paramount role as a propelling mechanism of mud diapirism.

\section{Experimental Procedure: Assemblies and Monitoring}

After preparing the mud mixtures, the assembly of the designed experiment continued. Therefore, it was necessary to have a previously labeled box that showed the thickness of a $7 \mathrm{~cm}$ mud layer. When pouring the mud into the box, homogenization of the surface was continued, as well as the cleanup of the box walls. Immediately afterwards, $5 \mathrm{~mm}$ of an impermeable layer (flavorless jelly) was deposited. For preparation of each layer, $16 \mathrm{~g}$ of flavorless jelly (Leader Price) were dissolved in $150 \mathrm{~mL}$ of water. After two hours of drying this impermeable layer, a second impermeable layer of $5 \mathrm{~mm}$ was spread to ensure that no holes or conduits were left, through which mud fluids could escape. Then, $32 \mathrm{~g}$ of dissolved jelly in $300 \mathrm{~mL}$ of water resulted in an average thickness of $10 \mathrm{~mm}$ of impermeable layer. It was allowed to dry for approximately 5 hours. After this time, a $3 \mathrm{~cm}$ sand layer was added (Figure 4). The experimental work was performed at room temperature, with oscillations between 26 and $28{ }^{\circ} \mathrm{C}$, and, therefore, temperature was considered as a constant parameter. Pictures of the initial assembly configuration were taken. 
After this, each experiment was carefully set up and continuously monitored around the clock. Changes in morphology of the surface observed at different stages were measured, logged and photographed. Experimental data, such as measured heights at each stage of diapir evolution, were logged. Notes also included description of morphology changes. A regular grid was carved on the sand surface of the initial set up (at time $=0$ ) of each experiment in order to track changes in surface morphology.

\section{RESULTS AND DISCUSSION}

Clear differences were observed in the evolution of models set up with different TOC contents (Figure 5) by means of sequentially monitoring the assemblies (Figure 6). Successive heights were measured periodically, and the rising rate was further calculated. Data reveal that the mixtures with higher TOC reached the $h_{\max }$ at shorter reaction times as compared to those with lower TOC.

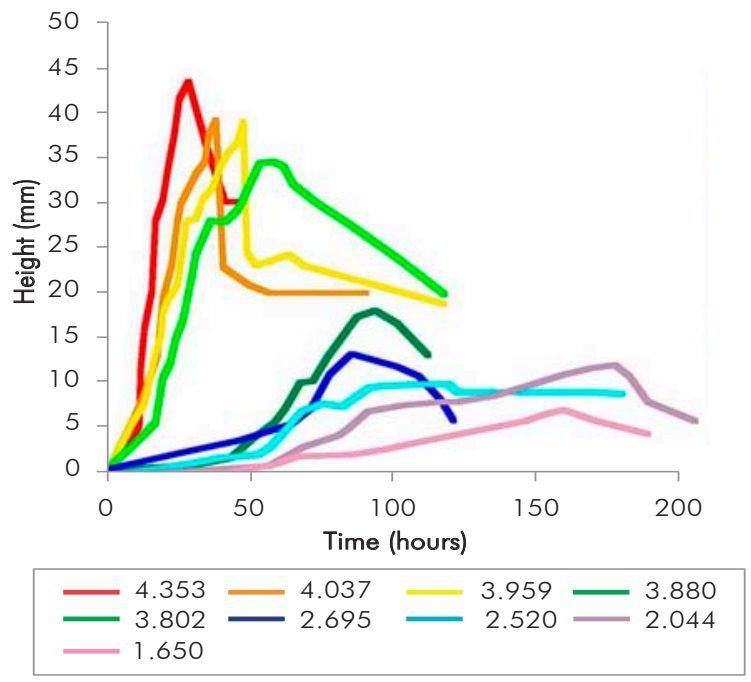

Figure 5. Temporary evolution of the experiments with 9 different TOC contents.
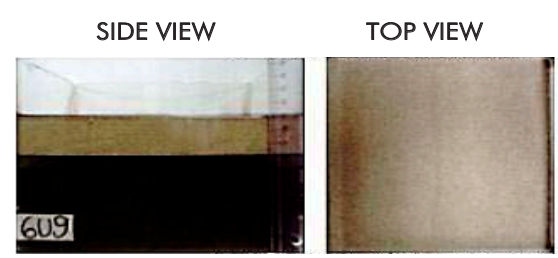

OBLIQUE VIEW
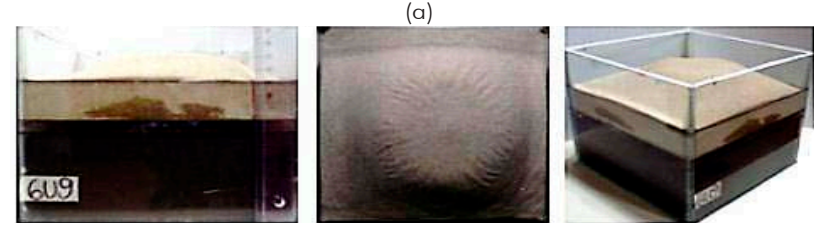

(b)
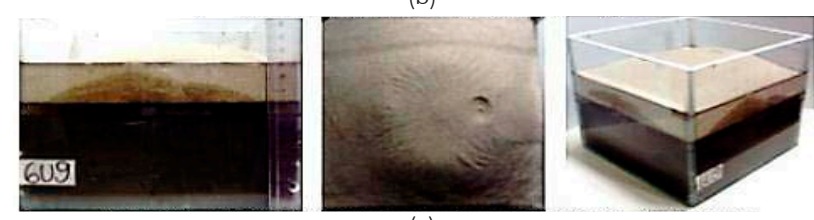

(c)
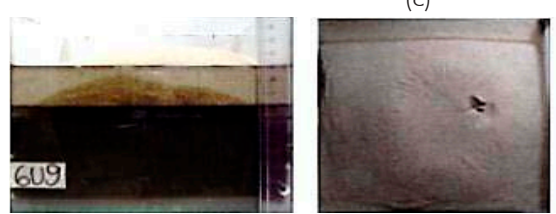

(d)
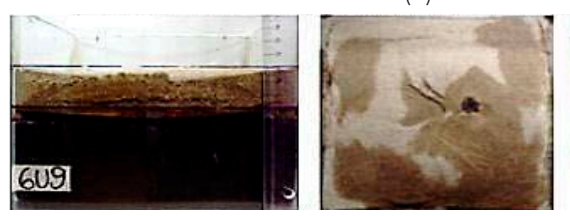

(e)
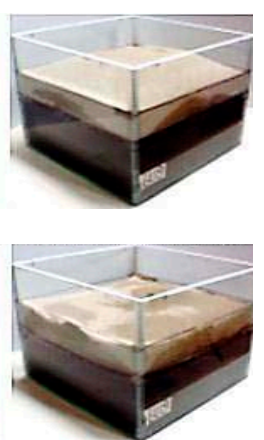

Figure 6. Example of data collected for experiment 6U9. Configuration of the assembly: A mud base with $4.35 \%$ TOC. Top view: $20 \mathrm{~cm} \times 20$ $\mathrm{cm}$. Side view: height $20 \mathrm{~cm}$. (a) $\mathrm{t}=0 \mathrm{~h}$. Initial set stage. $\mathrm{h}=0 \mathrm{~mm}$, (b) $t=20$ h. Maximum Height. $h=34 \mathrm{~mm}$, (c) $t=38 \mathrm{~h}$. Crater Formation. $\mathrm{h}=19 \mathrm{~mm}$, (d) $\mathrm{t}=50 \mathrm{~h}$. Crater Configuration Changes. $\mathrm{h}=19 \mathrm{~mm}$, (e) $t=110 \mathrm{~h}$. Final stage. Surface deformation by collapse.

The mixture with $4.353 \%$ of TOC reached the $h_{\max }$ at $~$ 28 hours, whereas that with $2.044 \%$ of TOC reached the $h_{\max }$ at $\sim 180$ hours. The $h_{\max }$ reached by diapiric domes are shown in Table 3. Time that these domes took to reach their $h_{\max }$ is condensed in Table 4 .

Table 3. Maximum heights reached by diapiric domes with different TOC concentrations.

\begin{tabular}{|c|c|c|c|c|c|c|c|}
\hline \multirow{2}{*}{ TOC (\%) } & \multicolumn{5}{|c|}{$\mathrm{h}_{\text {máx }}(\mathrm{mm})$} & \multirow{2}{*}{$\begin{array}{c}\text { Average } h_{\text {máx }}(\mathrm{mm}) \\
\text { RUNS 1-5 }\end{array}$} & \multirow{2}{*}{$\begin{array}{l}\text { Standard } \\
\text { deviation }\end{array}$} \\
\hline & RUN 1 & RUN 2 & RUN 3 & RUN 4 & RUN 5 & & \\
\hline 1.650 & 3 & 12 & 0 & 7 & 0 & 4.4 & 5.1 \\
\hline 2.044 & 8 & 5 & 12 & 7 & 15 & 9.4 & 4.0 \\
\hline 2.520 & 12 & 11 & 10 & 10 & 10 & 10.6 & 0.9 \\
\hline 2.695 & 17 & 13 & 24 & 20 & 10 & 16.8 & 5.5 \\
\hline 3.802 & 18 & 22 & 25 & 19 & 19 & 20.6 & 2.9 \\
\hline 3.881 & 32 & 34 & 31 & 27 & 29 & 30.6 & 2.7 \\
\hline 3.959 & 31 & 36 & 35 & 31 & 39 & 34.4 & 3.4 \\
\hline 4.037 & 34 & 40 & 47 & 39 & 32 & 38.4 & 5.9 \\
\hline 4.355 & 43 & 44 & 39 & 38 & 34 & 39.6 & 4.0 \\
\hline
\end{tabular}


Table 4. Time taken by diapiric domes to reach their maximum height for different TOC concentrations.

\begin{tabular}{|c|c|c|c|c|c|c|}
\hline \multirow{2}{*}{ TOC (\%) } & \multicolumn{5}{|c|}{$t_{\text {máx }}(h)$} & \multirow{2}{*}{$\begin{array}{c}\text { Average } \\
t_{\text {máx }}(h)\end{array}$} \\
\hline & RUN 1 & RUN 2 & RUN 3 & RUN 4 & RUN 5 & \\
\hline 1.650 & 118 & 170 & \multicolumn{3}{|c|}{158} & 148.7 \\
\hline 2.044 & 139 & 82 & 117 & 104 & 146 & 117.6 \\
\hline 2.520 & 137 & 95 & 91 & 91 & 95 & 101.8 \\
\hline 2.695 & 138 & 84 & 124 & 124 & 89 & 111.8 \\
\hline 3.802 & 113 & 106 & 122 & 91 & 85 & 103.4 \\
\hline 3.881 & 54 & 53 & 52 & 45 & 42 & 49.2 \\
\hline 3.959 & 31 & 32 & 36 & 45 & 47 & 38.2 \\
\hline 4.037 & 21 & 34 & 39 & 38 & 24 & 31.2 \\
\hline 4.355 & 28 & 28 & 27 & 26 & 20 & 25.8 \\
\hline
\end{tabular}

\section{Effect of TOC Concentration in the $h_{\max }$ of Diapirs}

To quantify the degree and type of correlation between TOC and $h_{\max }$, trend analyses via linear regression were performed on the data (Figure 7). Equation 1 resulted from linear regression of data in Table 3, rendering a $0.91 \mathrm{R}^{2}$, which indicates positive correlation between the real data (measured heights) and the numerical model (regression line).

$h_{\max }=12.7074 \times$ TOC -18.1585

The correlation found between TOC concentration and $h_{\max }$ may represent a useful tool in geological exploration of the subsurface. Should a correlation be proven on field data from mobile shale environments, relative variations in the height of the mud diapirs could be used to predict the concentration of organic matter in diapiric shale underneath. This correlation may have important implications in evaluating the potential of source rocks at sedimentary basins with presence of mud volcanoes and diapirs such as the Sinú basin in NW Colombia.

\section{Effect of TOC in Rates of Diapir Uplift and Collapse}

Data shown in Table 4 show an inverse relationship between TOC and the time spent by diapirs to reach their $h_{\max }$. Linear regression allowed us to investigate this hypothetical relationship (Figure 8). By using only the average values for this analysis, the following equation was obtained:

$t=-40.9273878 \times$ TOC +212.472057

where $t$ indicates time expressed in hours, and TOC is given in percentage. The correlation coefficient was 0.9. The positive correlation between rising time and

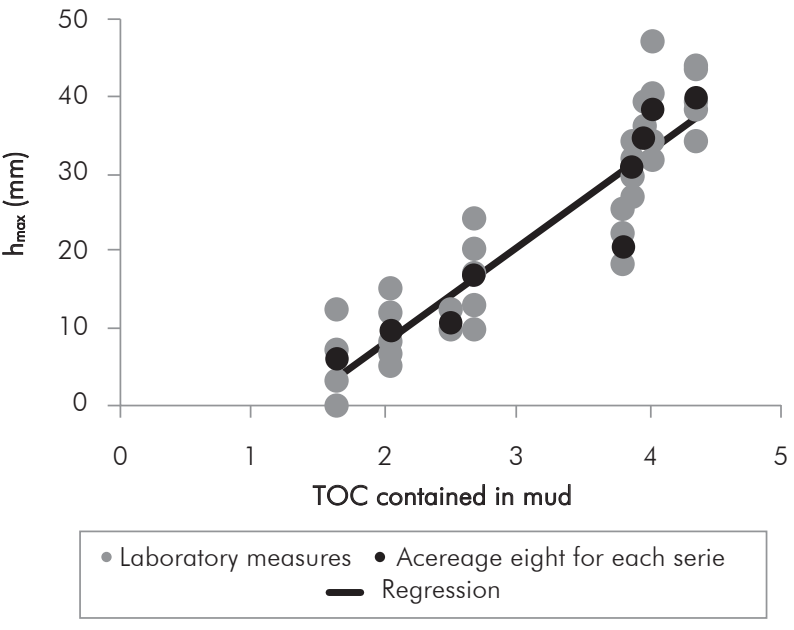

Figure 7. TOC vs. maximum height reached by diapiric domes using all values measured for each TOC.

TOC may be applied in organic geochemistry studies in areas of shale tectonics to better understand lateral variations concentration of organic matter in the subsurface. In this case, if accurate uplift rates and ages exist for a given diapir, these data may be used to infer the concentration of organic matter in the underlying subsurface.

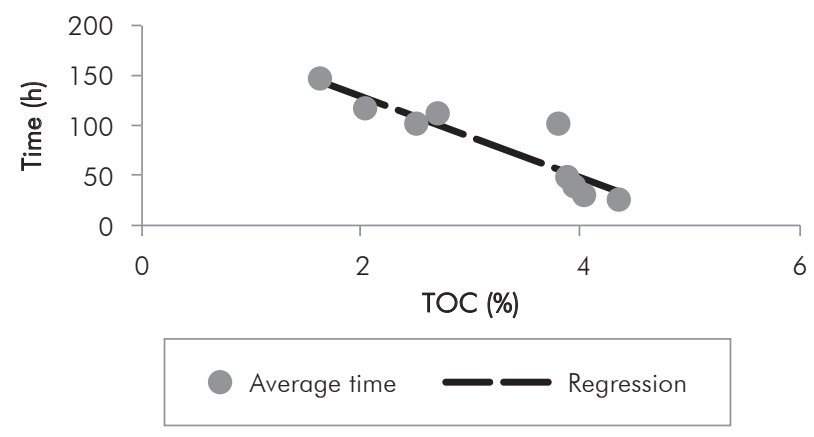

Figure 8. TOC vs. time taken by diapirs to reach their maximum height. 


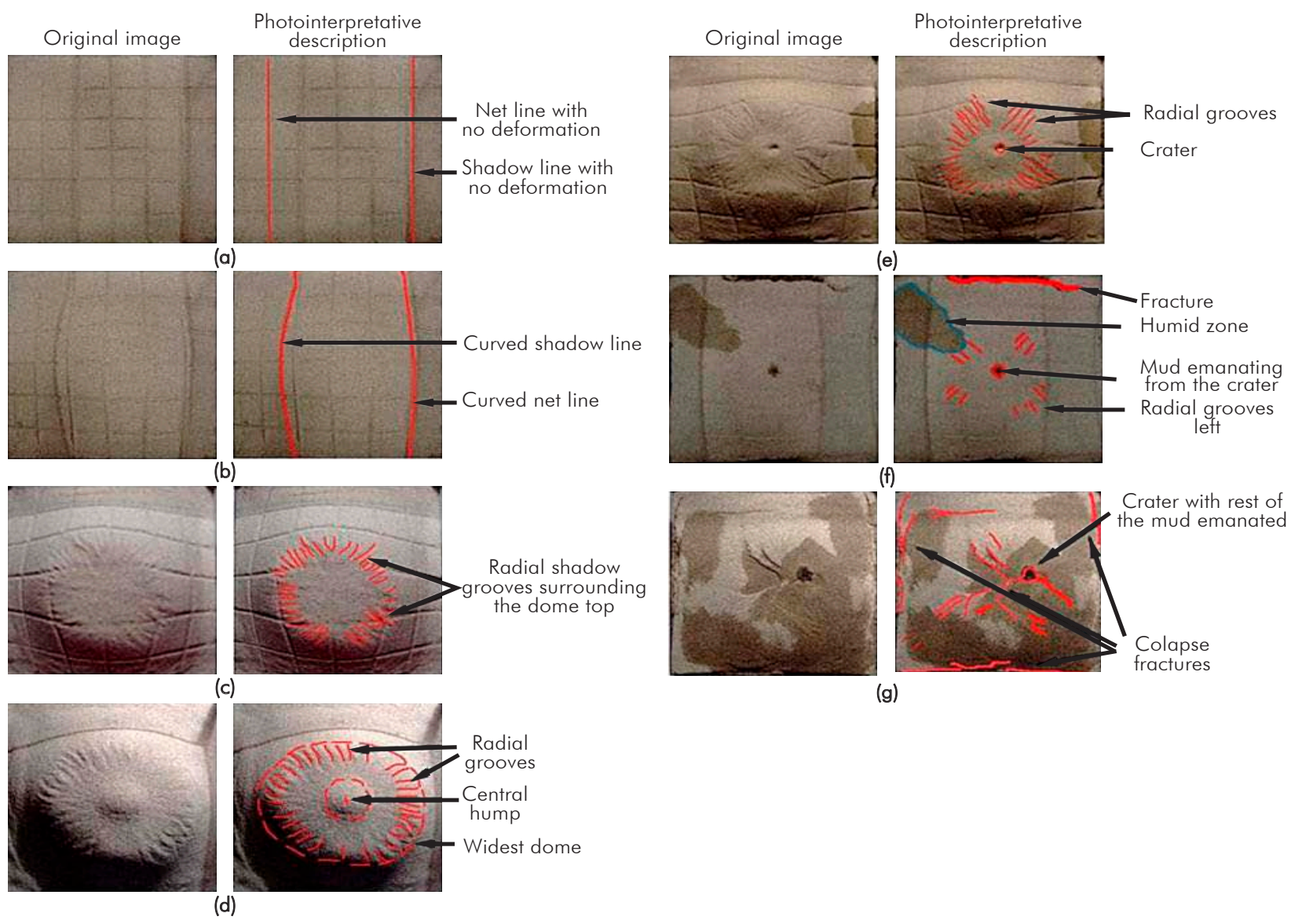

Figure 9. Evolution Stages of the experiments. Overhead view. Left: Original image. Right: Photointerpretation. (a) Stage 0: No surface deformation. Notice the straight lines of shadows and net. (b) Stage 1: Initial swelling up, initial deformation on the surface. Notice the curved shadow and net lines. (c) Stage 2: Grooves Formation. (d) Stage 3: Central Hump Formation. (e) Dome explosion and formation of a crater. (f) Collapsing of the structure (with mud and gas emanations). (g) Final sinking: Notice a very deformed and fracture surface.

\section{Stages of Evolution}

Experimental work reveals distinct morphological changes through time. Their morphology, duration and $h_{\max }$ may be grouped in the evolutionary stages displayed in Figure 9 and described as follows:

\section{Stage 0 - Embryonic Stage}

This stage is the starting point of all experiments, and begins immediately after pouring in the top sand layer. It shows a flat surface without deformation (Figure 9a).

\section{Stage 1 - Incipient Swell}

An incipient symmetric dome is observed. Assemblies with low TOC concentrations (1.6500, 2.0440, 2.5200 and $2.9650 \%$ ), reached their $h_{\max }$ in this stage (Figure 9b).

\section{Stage 2 - Groove Formation}

Shallow grooves are formed in the summit of the dome.
A radial drainage pattern typically develops. Elevation increases considerably relative to stage 1 . Assemblies with concentrations of TOC of 3.8020 (Figure 9c) and $3.8807 \%$ reached their $h_{\max }$ in stage 2 .

\section{Stage 3 - Central Hump Formation}

Models in this stage show a central hump that stands out an additional 3 to $4 \mathrm{~mm}$ above the main dome. Assemblies with the greatest TOC concentrations (3.9592, 4.0373 and $4.3553 \%)$ reached their $h_{\max }$ in this stage (Figure 9d).

\section{Stage 4 - Eruption and Crater Formation}

Diapirs start to emanate gas as evidenced by a fetid scent (in assemblies with TOC of $3.8020 \%$ or above). In some cases, the entire dome subsides abruptly. Eruption leaves a crater in the summit of the dome (in assemblies with TOC of 3.8020, 3.8807, 3.9592, 4.0373 and $4.3553 \%$ ) (Figure 9e). 


\section{Stage 5 - Structure Collapse}

The height of the dome decreases between 15 and $30 \%$. Collapse may be accompanied by mud discharge.

\section{Stage 6 - Final Sinking}

After collapse in stage 5, assemblies with high TOC (3.9592, 4.0373 and 4.3553\%) showed a dramatically deformed surface, characterized by large cracks near the model lateral faces (Figure 9g).

These evolution stages allowed us to identify the general characteristics that may be extrapolated to the areas affected by shale tectonics. Geomorphological and photogeological studies may help define the evolutionary stage of diapirism. For example, stages 2 and 3 display radial drainage patterns which may be interpreted as an early stage of evolution. Stage 4, would correspond to areas where diapirism is expressed as surface mud volcanism due to the presence of craters as well as gas seepage and mud discharge. In areas where active mud volcanoes have reached stages 5 or 6 , surface instability may follow in addition to gas seepage.

\section{Applications to the Colombian Caribbean Margin}

Duque-Caro (1979, 1984) described morphological characteristics in the Sinú Belt that show remarkable similarities with the physical models developed in this study. According to Duque-Caro (1984), the surface topography of the Sinú Belt may be grouped in two geomorphic families: (a) isolated mud volcanoes that emerge following the strike of the belt, and (b) large, conical hills of deformed strata that characterize the Abibe-Las Palomas and Turbaco anticlines. The axial area of the Abibe-Las Palomas anticline exhibits the greatest degree of deformation in the Sinú Belt, with average dips between $45^{\circ}$ and $10^{\circ}$. Here, two distinctive hills emerge in the area of the Quimari High, the highest and most prominent mountain in the region (2200 $\mathrm{m}$ in elevation). The hills of the Abibe-Las Palomas anticline are narrow, sloping and elongated structures

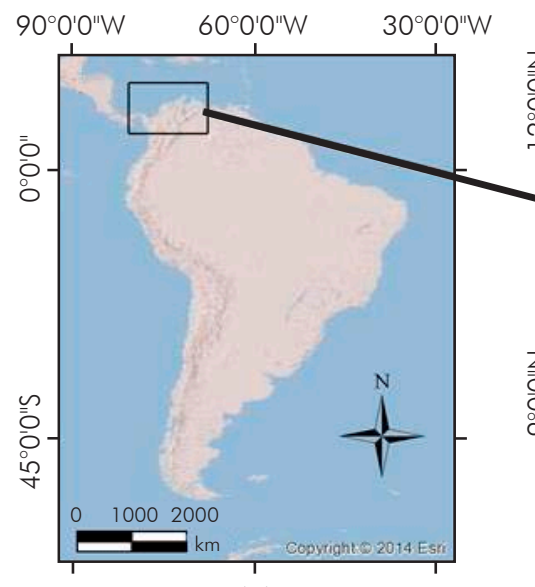

(a)

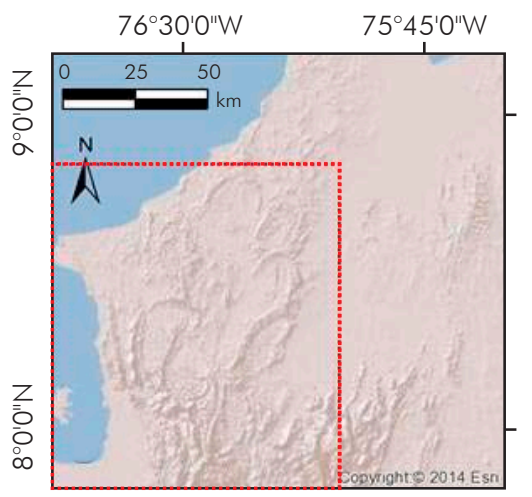

(c)
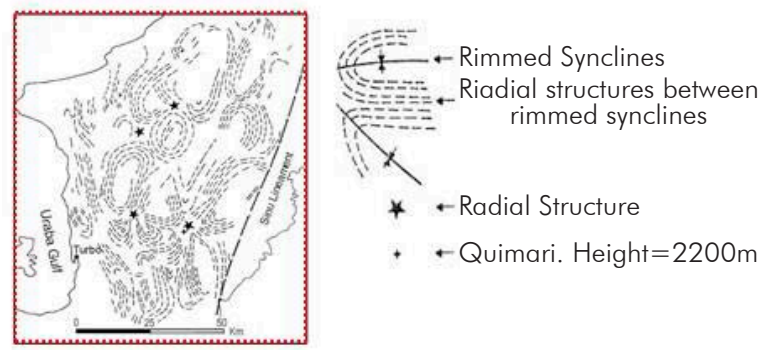

(d)

Figure 10. Sinú Belt general location. (a) Northern Colombia. (b) Sinú Belt in relation to Abibe-Las Palomas area. (c) 90 m-resolution shaded relief of the Abibe-Las Palomas area, from Shuttle Radar Topography Mission (SRTM) satellite topography, imagery developed by Esri ${ }^{\circ} 2014$. (d) Duque-Caro's 1984 structural interpretation of aerial photography and radar data, sixteen years before SRTM data was available. 


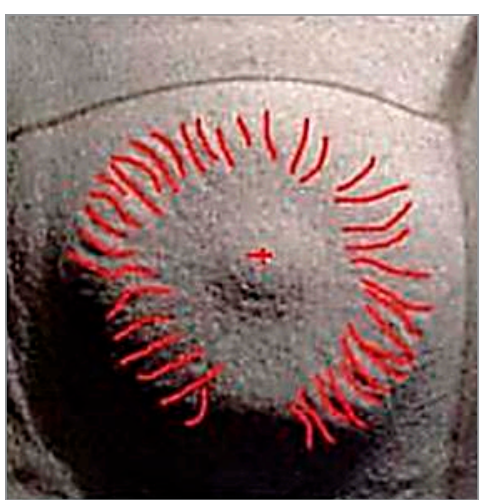

(a)

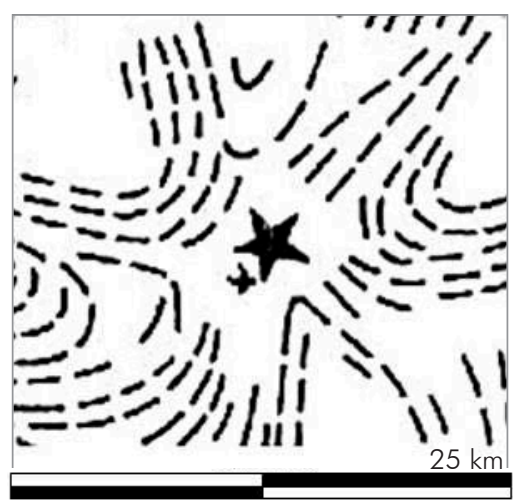

(b)

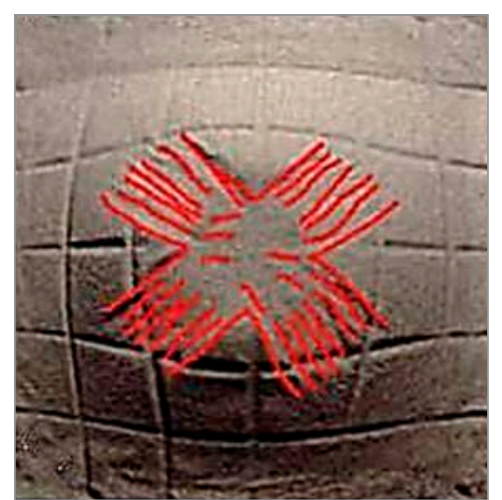

(c)

Figure 11. Comparison of patterns observed in the experiments (a) and (c) with those described by Duque-Caro in 1984 for Abibe-Las Palomas Area in the Sinú Belt, Colombian Caribbean (b). On the sides: Lab Models (20 x 20 cm Overhead view). In the center: Outline of the Quimari Hight (Detail of Figure 10).

that coincide with the highest topography, and are surrounded by four or more rimmed synclines. Radial drainages, divergent from the centers of the structures, have been clearly documented by Duque-Caro (1984) in the Quimari High, and by González and Londoño (2001) near Arjona and Cartagena (Figure 10). In contrast, anticlines in the Turbaco anticlinorium in the north display strata that are less deformed than those of the Abibe-Las Palomas, with average dips of $10^{\circ}$ (Duque-Caro, 1984).

The geomorphological features described by DuqueCaro (1984) for the Abibe-Las Palomas Anticlinorium closely resemble features observed in stages 2 and 3 (Figure 11). In these stages, radially divergent patterns in the summit of the domes are observed. These patterns may be related to the radial drainage observed by DuqueCaro (1984). Therefore, it is proposed that the AbibeLas Palomas anticlinorium is reaching its maximum elevation point. Keeping in mind the relationships between $h_{\max }$ - TOC and the TOC - evolution stage previously discussed, the high topography in the AbibeLas Palomas possibly coincides with areas of rich organic matter in the subsurface.

Two anticlinoria have been defined in the Sinú Belt, with clear differences in height: The southern and more elevated Abibe-Las Palomas; and the northern, narrower and less elevated Turbaco anticlorium. Isolated mud volcanoes are observed in both structures. According to inferences from the physical models developed in this study, the Abibe-Las Palomas anticlinorium can

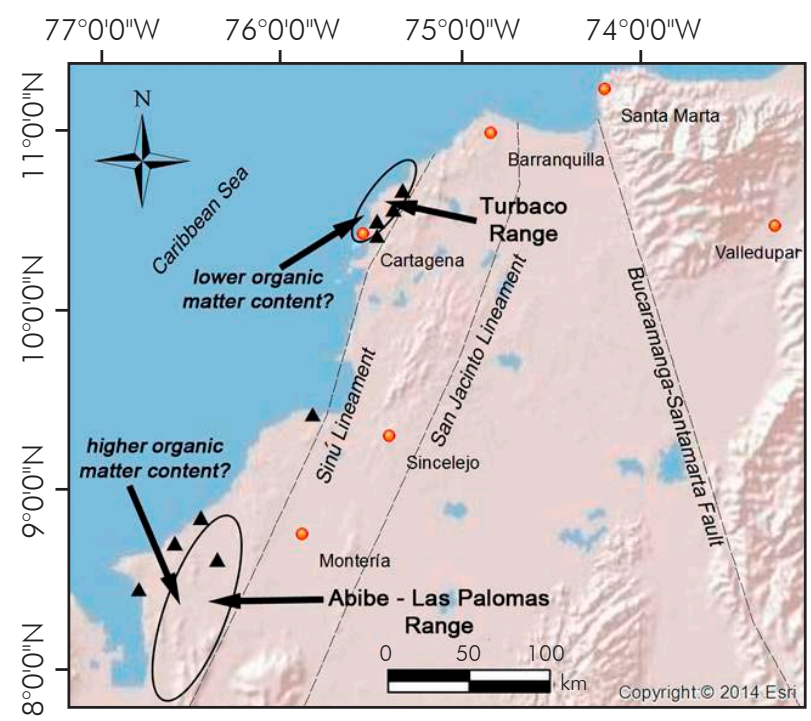

- Mud volcanism / diapirism - - Structures and lineaments - City

Figure 12. Predicted depocenters of higher contents of organic matter inland within the Sinú Belt, Colombian Caribbean Coast are shown circled. Greater elevations in Abibe - Las Palomas may reflect higher contents of organic matter in the subsurface than those under the Turbaco Anticlinorium to the north. Shaded relief imagery developed by Esri $^{\circledR} 2014$.

be considered as an area where thick mud reservoirs contain greater concentrations of organic matter than depocenters under the Turbaco Anticlinorium. These analogies allow us to trace tentative limits of geological provinces in the subsurface, based solely on observation of their surface morphology and topography. As a result, possible depocenters of higher contents of organic 
matter in depth have been traced on maps (Figure 12). This map may be used as an exploration tool upon field validation. Such a map may be used to predict the sites where the richest source rock may lie in the subsurface. Finally, the evolution of these structures suggests that areas affected by mud diapirism and mud volcanism, of the style presented here, may be subject of rapid subsidence after exhaustion of extruded materials, i.e. gases and mud, placing constructions above them at risk of damage during collapse of diapiric dome. Subsidence associated with mud volcanoes has been reported within several sites of the Sinú Belt by the Servicio Geológico Colombiano (Carvajal et al., 2011).

\section{CONCLUSIONS}

- Analog modeling in geology is a simplification of geological phenomena occurring in Earth, and, therefore, this method can be used to model and investigate the process of formation of mud diapirism and volcanism, whose in-situ properties may be not very well known. Therefore, our lack of knowledge about such geological process is one of the major limitations. All analogue models have limitations, which depend on the complexity of the geological phenomenon.

- Physical analog modeling demonstrates that they would provide a reasonable approximation of mud diapirism in nature, with organic matter content in the underlying mud that originates diapiric structures and TOC having a direct effect on their evolution (represented in their $h_{\max }$ ) and the time they take to reach their $h_{\max }$.

- Gas generated by decomposition of organic matter contained in mud plays a decisive role in the formation of diapiric structures. That is to say, gas serves as a propelling mechanism of the system, originating conduits through which mud can ascend and in some cases reach the surface.

- The $h_{\max }$ reached by diapiric domes produced in the laboratory are directly proportional to TOC concentration in the experimental mud.

- The time required by each diapir in our assemblies to reach $h_{\max }$ is inversely proportional to the TOC concentration of experimental mud.

- Six discernible evolutionary stages may be identified in diapiric domes. Only those assemblies with relatively large TOC contents experience all six stages, but in turn they evolve more rapidly and thus have shorter lives.

- Geomorphological similarities exist among structures obtained in our experiments and those described in the Sinú Belt of Colombia by Duque-Caro (1984). According to geomorphological and structural differences within the Sinú Belt, two areas may be discriminated: (A) the Abibe - Las Palomas Anticlinorium to the south, of higher elevation and greater internal deformation than (B) the Turbaco Anticlinorium to the north, of lower elevation and less internal deformation. Organic matter depocenters related to active mud diapirism may have bigger concentrations of organic matter in the Abibe - Las Palomas than in the Turbaco Anticlinorium. Finally, constructions above these areas may be exposed to damage during collapse of the diapiric dome.

\section{ACKNOWLEDGEMENTS}

This research is part of the undergraduate thesis of Olivia González and Alfonso-Luis Rodríguez. The authors gratefully acknowledge the Universidad Industrial de Santander for providing facilities to develop the experimental work. The authors wish to thank to geochemist Luis Miguel Bernardo from Ecopetrol S.A.Instituto Colombiano de Petróleo (ICP) for providing TOC analysis for the different mud mixtures and the Corporación Geológica ARES for financial support provided for this research project. Finally, the authors are most grateful to the above-named people and institutions for their support.

\section{REFERENCES}

Antonielli, B., Monserrat, O., Bonini, M., Righini, G., Sani, F., Luzi, G., Feyzullayev, A. A. \& Aliyev, C. S. (2014). Pre-eruptive ground deformation of Azerbaijan mud volcanoes detected through satellite radar interferometry (DInSAR). Tectonophysics, 637: 163-177. 
Beauchamp, B. (2004). Natural gas hydrates: Myths, facts and issues. C. R. Geosci., 336, 751-765.

Briceño, L. A. \& Vernette, G. (1992). Manifestaciones del diapirismo arcilloso en el margen colombiano del Caribe. Geofís. Colombiana, 1: 21-30.

Brown, K. M. (1990). The nature and hydrogeologic significance of mud diapirs and diatremes for accretionary systems. J. Geophys. Res., 95(B6), 8969-8982.

Brown, K. M. \& Westbrook, G. K. (1988). Mud diapirism and subcretion in the Barbados Ridge accretionary complex: The role of fluids in accretionary processes. Tectonics, 7(3), 613-640.

Carvajal, J. H., Mendivelso, D., Obando, G., Forero, H., Gómez, J. F., Vásquez, L., Cárdenas, R., Castiblanco, C. R., Franco, J. V., Ruge, G., Pinzón, L., Prada, M. A. \& Imbachi, O. (2011). Características del 'Volcanismo de Lodo’ del Caribe Central Colombiano. Ministerio de Minas y Energía. Informe Servicio Geológico Colombiano, Bogotá.

Charlou, J. L., Donval, J. P., Zitter, T., Roy, N., Jean-Baptiste, P., Foucher, J. P. \& Woodside, J. (2003). Evidence of methane venting and geochemistry of brines on mud volcanoes of the eastern Mediterranean Sea. Deep-Sea Res. Pt I, 50(8), 941-958.

Chen, S. C., Hsu, S. K., Wang, Y., Chung, S. H., Chen, P. C., Tsai, C. H., Liu, C. S., Lin, H. S. \& Lee, Y. W. (2014). Distribution and characters of the mud diapirs and mud volcanoes off southwest Taiwan. J. Asian Earth Sci. 92: 201-214.

Dimitrov, L. I. (2002). Mud volcanoes - the most important pathway for degassing deeply buried sediments. EarthSci. Rev., 59: 49-76.

Duque-Caro, H. (1979). Geotectónica y evolución de la región Noroccidental Colombiana. Bol. Geol. Ingeominas, 23(3), 4-37.

Duque-Caro, H. (1984). Estilo estructural, diapirismo y episodios de acrecimiento del terreno Sinú-San Jacinto en el Noroccidente de Colombia. Bol. Geol. Ingeominas, 27(2), 1-29.
Gamberi, F. \& Rovere, M. (2010). Mud diapirs, mud volcanoes and fluid flow in the rear of the Calabrian Arc Orogenic Wedge (southeastern Tyrrhenian sea). Basin Res., 22(4), 452-464.

Gao, S., House, W. \& Chapman, W.G. (2005). NMR/MRI study of clathrate hydrate mechanisms. J. Phys. Chem. B, 109(41), 19090-19093.

González, H. \& Londoño, A. (2001). Mapa geológico del departamento de Córdoba. Geología, recursos minerales y amenazas naturales. Escala 1:250.000, Ingeominas.

Guliyiev, I. S. \& Feizullayev, A. A. (1997). All about mud volcanoes. Azerbaijan: Publ. House, Nafta Press, Baku.

Hedberg, H. D. (1974). Relation of methane generation to undercompacted shales, shale diapirs and mud volcanoes. AAPG Bull., 58(4), 661-673.

Hensen, C., Nuzzo, M., Hornibrook, E., Pinheiro, L. M., Bock, B., Magalhães, V. \& Bruckmann, W. (2007). Sources of mud volcano fluids in the Gulf of Cadiz: Indications for hydrothermal imprint. Geochim. Cosmochimica Acta, 71(5), 1232-1248.

Hester, K. C. \& Brewer, P. G. (2009). Clathrate hydrates in nature. Ann. Rev. Mar. Sci., 1, 303-327.

Higgins, G. E. \& Saunders, J. B. (1974). Mud volcanoes - Their nature and origin, contributions to geology and palaeobiology of Caribbean and adjacent areas. Verh. Naturforsch. Ges. Basel, 84: 101-152.

Hovland, M., Hill, A. \& Stokes, D. (1997). The structure and geomorphology of the Dashgil mud volcano, Azerbaijan. Geomorphology, 21(1), 1-15.

Jakubov, A. A., Ali-Zade, A. A. \& Zeinalov, M. M. (1971). Mud volcanoes of the Azerbaijan SSR: Atlas. Elm-Azerbaijan Acad. Sci. Pub. House, Baku.

Judd, A. G. \& Hovland, M. (2007). Seabed fluid flow: The impact on geology, biology, and the marine environment. Cambridge: Cambridge University Press.

Kobayashi, K., Ashi, J., Boulegue, J., Cambray, H., ChamotRooke, N., Fujimoto, H., Furuta, T., Iiyama, J. T., Koizumi, T., Mitsuzawa, K., Monma, H., Murayama, M., Naka, J., Nakanishi, M., Ogawa, Y., Otsuka, K., Okada, 
M., Oshida, A., Shima, N., Soh, W., Takeuchi, A., Watanabe, M. \& Yamagata, T. (1992). Deep-tow survey in the KAIKO-Nankai cold seepage areas. Earth Planet. Sci. Lett., 109: 347-354.

Kopf, A. J. (2002). Significance of mud volcanism. Rev. Geophys., 40(2), 1-52.

Kopf, A. J. (2003). Global methane emission through mud volcanoes and its past and present impact on the Earth's climate. Int. J. Earth Sci., 92(5), 806-816.

Kopf, A., Robertson, A. H. F. \& Volkmann, N. (2000). Origin of mud breccia from the Mediterranean Ridge accretionary complex based on evidence of the maturity of organic matter and related petrographic and regional tectonic evidence. Mar. Geol., 166(1-4), 65-82.

Krastel, S., Spiess, V., Ivanov, M., Weinrebe, W., Bohrmann, G., Shashkin, P. \& Heidersdorf, F. (2003). Acoustic investigations of mud volcanoes in the Sorokin Trough, Black Sea. Geo-Mar. Lett., 23(3), 230-238.

León, R., Somoza, L., Medialdea, T., González, F. J., Díazdel-Río, V., Fernández-Puga, M. C., Maestro, A. \& Mata, M. P. (2007). Sea-floor features related to hydrocarbon seeps in deepwater carbonate-mud mounds of the Gulf of Cádiz: from mud flows to carbonate precipitates. Geo-Mar. Lett. 27(2), 237-247.

Lundgaard, L. \& Mollerup, J. (1992). Calculation of phase diagrams of gas-hydrates. Fluid Phase Equilibr., 76: 141-149.

Mantilla-Pimiento, A. M., Jentzsch, G., Kley, J. \& AlfonsoPava, C. (2009). Configuration of the Colombian Caribbean Margin: Constraints from 2D seismic reflection data and potential fields interpretation. In: Lallemand, S. \& Funiciello. F. (eds.). Subduction zone geodynamics. Berlin: Springer-Verlag Berlin Heidelberg. 247-272.

Martin, J. B., Kastner, M., Henry, P., Le Pichon, X. \& Lallement, S. (1996). Chemical and isotopic evidence for sources of fluids in a mud volcano field seaward of the Barbados accretionary wedge. J. Geophys. Res., 101(B9), 20325-20345.

Michon, L. \& Merle, O. (2003). Mode of lithospheric extension: Conceptual models from analogue modeling. Tectonics, 22(4), 1-16.
Milkov, A. V. (2000). Worldwide distribution of submarine mud volcanoes and associated gas hydrates. Mar. Geol., 167(1-2), 29-42.

Morita, S., Ashi, J., Aoike, K. \& Kuramoto, S. (2004). Evolution of Kumano basin and sources of clastic ejecta and pore fluid in Kumano mud volcanoes, Eastern Nankai Trough. International Symposium on Methane Hydrates and Fluid Flow in Upper Accretionary Prisms, Kyoto University, Kyoto.

Nishio, Y., Ijiri, A., Toki, T., Morono, Y., Tanimizu, M., Nagaishi, K. \& Inagaki, F. (2015). Origins of lithium in submarine mud volcano fluid in the Nankai accretionary wedge. Earth Planet. Sci. Lett., 414: 144-155.

O’Brien, G. D. (1968). Survey of diapirs and diapirism. In: Braustein, J. \& O’Brien, G.D., (eds). Diapirism and diapirs. AAPG Mem. 8, 1-9.

Ojeda, G. Y., Hernández, R. \& Olaya, I. D. (2004). Mud volcanoes on the seafloor of the Colombian Caribbean Sea: Undesirable lumps or exploration tools?. 2nd Technical Convention, ACGGP, Bogota, Colombia.

Ordoñez, C. I. (2008). Controle neotectónico do diapirismo de lama na regiao de Cartagena, Colombia. M. Sc. Thesis, Universidade Federal Fluminense, Brazil, 224pp.

Palomino, D., López-González, N., Vázquez J. T., FernándezSalas, L. M., Rueda, J. L., Sánchez-Leal, R. \& Díazdel-Río, V. (In Press). Multidisciplinary study of mud volcanoes and diapirs and their relationship to seepages and bottom currents in the Gulf of Cádiz continental slope (northeastern sector). Mar. Geol.

Pérez-Belzuz, F., Alonso, B. \& Ercilla, G. (1997). History of mud diapirism and trigger mechanisms in the Western Alboran Sea. Tectonophysics, 282(1-4), 399-422.

Perez-Garcia, C. (2012). A multidisciplinary subsurface analysis of mud volcanoes and salt diapirs in European Seas. Ph. D. Thesis, Faculty of Science and Technology, University of Tromsø, Norway. 33pp.

Reed, D. L., Silver, E. A., Tagudin, J. E., Shipley, T. H. \& Vrolijk, P. (1990). Relations between mud volcanoes, thrust deformation, slope sedimentation and gas hydrates, offshore north Panama. Mar. Petrol. Geol., 7(1), 44-54. 
Robertson, A. (1996). Mud volcanism on the Mediterranean Ridge: Initial results of ocean drilling program Leg 160. Geology, 24(3), 239-242.

Robertson, A. \& Kopft, A. (1998). Tectonic setting and processes of mud volcanism on the Mediterranean, Ridge accretionary complex: Evidence from Leg 160. Procedings of Ocean Drilling Program, Scientific Results, 160.

Schellart, W. P. (2002). Analogue modelling of large-scale tectonic processes: An introduction. J. Virtual Explorer, 7: $1-6$.

Sautkin, A., Talukder, A. R., Comas, M. C., Soto, J. I. \& Alekseev, A. (2003). Mud volcanoes in the Alboran Sea: Evidence from micropaleontological and geophysical data. Mar. Geol., 195(1-4), 237-261.

Servio, P., Lagers, F., Peters, C. \& Englezos, P. (1999). Gas hydrate phase equilibrium in the system methane-carbon dioxide-neohexane and water. Fluid Phase Equilibr., 158-160: 795-800.

Shipley, T. H., Stoffa, P. L. \& Dean, D. F. (1990). Underthrust sediments, fluid migration paths, and mud volcanoes associated with the accretionary wedge off Costa Rica: Middle America Trench. J. Geophys. Res., 95(B6), 87438752.

Sloan, E. D. Jr, (2003). Fundamental principles and applications of natural gas hydrates. Nature, 426: 353-363.

Somoza, L., Díaz-del-Río, V., León, R., Ivanov, M., Fernández-Puga, M. C., Gardner, J. M., HernándezMolina, F. J., Pinheiro, L. M., Rodero, J., Lobato, A., Maestro, A., Vázquez, J. T., Medialdea, T. \& FernándezSalas, L. M. (2003). Seabed morphology and hydrocarbon seepage in the Gulf of Cádiz mud volcano area: Acoustic imagery, multibeam and ultra-high resolution seismic data. Mar. Geol., 195(1-4), 153-176.

Sumner, R. H. \& Westbrook, G. K. (2001). Mud diapirism in front of the Barbados accretionary wedge: The influence of fracture zones and North America-South America plate motions. Mar. Petrol. Geol., 18(5), 591-613.

Talukder, A. R., Bialas, J., Klaeschen, D., Buerk, D., Brueckmann, W., Reston, T. \& Breitzke, M. (2007). High-resolution, deep tow, multichannel seismic and sidescan sonar survey of the submarine mounds and associated BSR off Nicaragua pacific margin. Mar. Geol., 241(1-4), 33-43.

Uchida, T., Ohmura, R., Ikeda, I. Y., Nagao, J., Takeya, S. \& Hori, A. (2006). Phase equilibrium measurements and crystallographic analyses on structure- $\mathrm{H}$ type gas hydrate formed from the $\mathrm{CH}_{4}-\mathrm{CO}_{2}$-neohexane-water system. $\mathrm{J}$. Phys. Chem. B, 110(10), 4583-4588.

Vernette, G. (1986). Le Diapirisme argileux et ses consequences sur les caracteres morphologiques et sédimentaires de la Marge Colombienne des Caraibes. Bull. l'Inst. Géol. Bassin d'Aquitaine, 40: 35-51.

Vernette, G., Mauffret, A., Bobier, C., Briceno, L. \& Gayet, J. (1992). Mud diapirism, fan sedimentation and strike-slip faulting, Caribbean Colombian Margin. Tectonophysics, 202(2-4), 335-349.

Yusifov, M. \& Rabinowitz, P. D. (2004). Classification of mud volcanoes in the South Caspian Basin, offshore Azerbaijan. Mar. Petrol. Geol., 21(8), 965-975.

\section{AUTHORS}

\section{Olivia González-Morales}

Affiliation: Universidad Industrial de Santander - Geoconsulting

Geologist, Universidad Industrial de Santander

e-mail: oligomor@yahoo.es

\section{Alfonso-Luis Rodríguez-Madrid}

Affiliation: RM GeoConsulting

Geologist, Universidad Industrial de Santander

M. Sc. in Geology, The University of British Columbia

e-mail: alfonsoluisroma@gmail.com

\section{Carlos-Alberto Ríos-Reyes}

Affiliation: Universidad Industrial de Santander Geologist, Universidad Industrial de Santander M. Sc. in Geology, University of Shimane Ph. D. in Applied Sciences, University of Wolverhampton e-mail: carios@uis.edu.co

\section{Germán-Yury Ojeda-Bueno}

Affiliation: Corporación Geológica Ares Geologist, Universidad Nacional de Colombia M. Sc. in Geology, University of South Carolina $\mathrm{Ph}$. D. in Geology (Geophysics), Florida International University Post-Doc, Coastal Carolina University e-mail: gojeda@cgares.org 